\title{
Reduction of slaughter age of Hanwoo steers by early genotyping based on meat yield index
}

\author{
Chang Dae Jeong ${ }^{1}$, Mahfuzul Islam ${ }^{1}$, Jong-Joo Kim², Yong-II Cho ${ }^{3}$, and Sang-Suk Lee ${ }^{1, *}$
}

* Corresponding Author: Sang-Suk Lee Tel: +82-61-750-3237, Fax: +82-61-750-3237,

E-mail: rumen@sunchon.ac.kr

${ }^{1}$ Ruminant Nutrition and Anaerobe Laboratory, Department of Animal Science and Technology, Sunchon National University, Suncheon 57922, Korea 2 Department of Biotechnology, Yeungnam University, Gyeongsan 38541, Korea

${ }^{3}$ Animal Disease and Diagnostic Laboratory, Department of Animal Science and Technology, Sunchon National University, Suncheon 57922, Korea

ORCID

Chang Dae Jeong

https://orcid.org/0000-0001-6567-4397 Mahfuzul Islam

https://orcid.org/0000-0001-6010-140X Jong-Joo Kim

https://orcid.org/0000-0001-9687-0075

Yong-ll Cho

https://orcid.org/0000-0001-7756-3416

Sang-Suk Lee

https://orcid.org/0000-0001-8804-3416

Submitted Jun 18, 2019; Revised Aug 23, 2019; Accepted Oct 3, 2019
Objective: This study was conducted to determine early hereditary endowment to establish a short-term feeding program.

Methods: Hanwoo steers $(\mathrm{n}=140)$ were equally distributed into four groups (35/group) based on genetic meat yield index (MYI) viz. the greatest, great, low, and the lowest at Jukam Hanwoo farm, Goheung. All animals were fed in group pens ( 5 animals/pen) with similar feed depending on the growth stage. Rice straw was provided ad libitum, whereas concentrate was fed at $5.71 \mathrm{~kg}$ during the growing period (6 to $13 \mathrm{mo}$ ) and $9.4 \mathrm{~kg}$ during the fattening period (13 to $28 \mathrm{mo}$ ). Body weight (BW) was measured at two-month intervals, whereas carcass weight was determined at slaughtering at about 31 months of age. The Affymetrix Bovine Axiom Array $640 \mathrm{~K}$ single nucleotide polymorphism (SNP) chip was used to determine the meat quantity-related gene in the blood.

Results: After 6 months, the highest $(\mathrm{p}<0.05)$ BW was observed in the greatest MYI group $(190.77 \mathrm{~kg})$ and the lowest $(\mathrm{p}<0.05)$ in the lowest MYI group $(173.51 \mathrm{~kg})$. The great MYI group also showed significantly $(\mathrm{p}<0.05)$ higher BW than the lowest MYI group. After 16 and 24 months, the greatest MYI group had the highest BW gain $(p<0.05)$ and were therefore slaughtered the earliest. Carcass weight was significantly $(\mathrm{p}<0.05)$ higher in the greatest and the great MYI groups followed by the low and the lowest MYI groups. Back-fat thickness in the greatest MYI group was highly correlated to carcass weight and marbling score. The SNP array analysis identified the carcass-weight related gene BTB-01280026 with an additive effect. The steers with the allele increasing carcass weight had heavier slaughter weight of about $12 \mathrm{~kg}$.

Conclusion: Genetic MYI is a potential tool for calf selection, which will reduce the slaughter age while simultaneously increasing carcass weight, back-fat thickness, and marbling score.

Keywords: Body Weight; Carcass Weight; Genotyping; Growth Pattern; Meat Yield Index

\section{INTRODUCTION}

The prime goal of the beef cattle industry is to provide highly desirable beef for consumers in the most efficient manner. The Hanwoo cattle breed has been subjected to intensive selection for meat quality and production traits [1], and, thus, a significant genetic improvement has been obtained for carcass weight and eye muscle area [2]. Hanwoo beef is considered the most expensive yet high-quality beef in Korea. One of the reasons is that Hanwoo farmers fatten their steers up to 30 to 32 months of age to improve the marbling score. However, Hanwoo meat qualities such as sirloin size, back-fat thickness, marbling score, and carcass weight are not significantly different between the slaughtering ages of 27 and 31 months. Additionally, the Hanwoo farmers do not raise their cattle for over 30 months because of the increase in feed cost. Therefore, the appropriate selection of calves or cows at an early stage is very important to ensure economic benefit by decreasing slaughtering age while 
simultaneously increasing meat quality.

In recent years several studies have reported the development of selection indexes to increase the efficiency of beef production. Production traits considered are weight of calf at weaning, post-weaning daily gain, age at slaughter after fattening, frequency of dystocia, milk yield, and body weight (BW) [3]. The choice of traits is different in each country owing to differences in biological, management, and economical production systems [4]. However, feed efficiency and growth rate generally have a strong association with the economics of gain. Heritability estimates for growth, based on live weight, weight gain, and carcass traits have been extensively reported in the literature as reviewed by Koots et al [5] and Rios-Utrera and Van-Vleck [6]. Genetic correlations between measures of growth or size at different ages are usually high. Selection for the rapid rate of gain in post-weaning feeding tests usually increases both birth weight and size at maturation. However, increases in birth weight also cause an increase in calving difficulties.

Recently, genome-wide association studies using high density single nucleotide polymorphism (SNP) chips have been used to detect the genetics of quantitative trait loci (QTL) in several domestic livestock species [7]. For instance, carcass traits such as carcass weight, eye muscle area, back-fat thickness, and marbling score are the critical quantitative traits affecting beef cattle production [1]. Thus, a genome-wide association study would help understand the molecular mechanisms that regulate beef production in Hanwoo cattle. Early assessment of carcass quality for a Hanwoo individual that is based on the genetics of the genotyped animal is desirable for farmers, because the information would assist in early selection or better feeding management practices. Therefore, the objective of this study was an early diagnosis of hereditary endowment, which will lead to the establishment of a decrease in the slaughtering age or carcass day based on the results of genetic predictions.

\section{MATERIALS AND METHODS}

\section{Animals and phenotype data}

A total of 140 Hanwoo steers were equally distributed into four treatments groups ( 35 in each group) at 6 months of age based on the genetic meat yield index (MYI) viz. the greatest, great, low, and the lowest group at the Jukam farm, Goheung, Jeonnam, Korea. The selection index (SI) and MYI were set up by Korean Institute for Animal Products Quality Evaluation, Sejong city and National Institute of Animal Science, Wanju, Chonbuk, Korea. The MYI was calculated as, MYI = $71.414-(0.625 \times$ backfat thickness $[\mathrm{mm}])+(0.130 \times$ loin eye muscle area $\left.\left[\mathrm{cm}^{2}\right]\right)-(0.024 \times$ carcass weight $[\mathrm{kg}])$. The SI of an individual was calculated as, $\mathrm{SI}=(1 \times \mathrm{EBV}$ of carcass weight $+1 \times \mathrm{EBV}$ of loin eye muscle area $-1 \times \mathrm{EBV}$ of backfat thickness
$+6 \times \mathrm{EBV}$ of marbling score), in which EBV is standardized estimated breeding value for each trait. The breeding values were predicted with pedigree information and carcass records of genetical relatives by Korea Animal Improvement Association, Seoul, Korea. The SI of the greatest, great, low, and the lowest MYI groups were 12.04 to $9.33,9.33$ to $8.50,8.50$ to 8.07 , and 8.07 to 2.91 , respectively. The first day BW was also collected from the farm record and included into analysis.

The steers were treated according to the recommendations described in "The Guide for the Care and Use of Laboratory Animals," published by the Institutional Animal Care and Use Committee (IACUC) of National Institute of Animal Science (2012-C-037) in Korea (IACUC APPROVAL NUMBER: SCNU-IACUC-2012-4). The experimental house was large enough to raise 140 steers at a time without any disturbances. The width $\times$ length of each pan was $5 \mathrm{~m} \times 10 \mathrm{~m}$ with feeder and waterer facilities. The experimental animals were fed in group pens (five animals/pen) with a similar amount of feed depending on the growth stage. Rice straw was provided ad libitum, whereas concentrate feed was fed at 5.71 $\mathrm{kg}$ during the growing period (6th to 13th months) and 9.4 $\mathrm{kg}$ during the fattening period (13th to 28th months). Feed ingredients (as-fed basis) and chemical composition (\% of dry matter) of the experimental diets used in the in vivo experiment are presented in Table 1. The BW was measured every two months, whereas carcass weight was determined after slaughter at approximately the 31st month of age. Average daily gain $(\mathrm{kg} / \mathrm{d}$ ) was measured as, ([BW of day 720 - BW of day 1]/720). The steers were slaughtered at the municipal slaughterhouse following the normal commercial slaughterhouse procedure. After $24 \mathrm{~h}$ post-slaughter chilling, carcass weight was measured and evaluated the carcasses based on the official grader of carcass traits following the Korean carcass grading standard (National Livestock Cooperatives Federation) [8]. Correlation analysis of growth patterns and carcass characteristics of Hanwoo steers were calculated along with the MYI.

\section{Genotyping and single nucleotide polymorphisms quality control}

Blood samples of 140 Hanwoo steers were collected for genotyping using Affymetrix Bovine Axiom Array 640k SNP chips. Quality controls were tested to screen available SNPs with PLINK version 1.07 [9], and the SNPs meeting the following criteria were removed: i) the frequency of the least genotype was less than ten, ii) the call rate was smaller than $95 \%$, iii) p-value of the Hardy-Weinberg equilibrium test was less than 0.001 , and iv) minor allele frequency was less than $5 \%$.

\section{Statistical analysis}

The phenotypic data were analyzed using the general linear model for randomized complete block design using SAS 
Table 1. Ingredients and chemical compositions of feeds used for in vivo experiment

\begin{tabular}{lccc}
\hline Parameters & $\begin{array}{c}\text { Growing feed } \\
\text { 6 to } 13 \text { mo }\end{array}$ & $\begin{array}{c}\text { Fattening feed } \\
\mathbf{1 3} \text { to } 28 \text { mo }\end{array}$ & $\begin{array}{c}\text { Rice } \\
\text { straw }^{1)}\end{array}$ \\
\hline Ingredients of concentrate feed (as-fed basis) & & \\
Corn & 23.36 & 22.30 & - \\
Wheat bran & 12.00 & 12.00 & - \\
Wheat flour & - & 1.00 & - \\
Wheat grain & 11.82 & 5.06 & - \\
Corn gluten feed & 14.00 & 9.70 & - \\
Molasses & 6.00 & 6.00 & - \\
Rapeseed meal & 9.00 & 5.00 & - \\
DDGS & - & 4.00 & - \\
Coconut Kernel Meal & 3.50 & 5.50 & - \\
Palm kernel meal & 14.00 & 14.00 & - \\
Tapioca & 2.92 & 12.50 & - \\
Salt dehydrated & 0.60 & 0.60 & - \\
Limestone (1 mm) & 2.25 & 2.04 & - \\
Vitamin premix & 0.30 & 0.20 & - \\
Mineral premix & 0.25 & 0.10 & - \\
Chemical Compositions (\% of DM) & & & \\
DM & 87.02 & 86.86 & 86.76 \\
CP & 14.00 & 13.99 & 6.41 \\
EE & 2.50 & 3.39 & 1.01 \\
Ash & 12.00 & 6.21 & 11.84 \\
CF & 18.00 & 8.93 & 32.24 \\
NDF & 37.00 & 39.29 & 86.50 \\
ADF & 15.00 & 17.04 & 55.20 \\
TDN & 69.23 & 74.11 & 49.80 \\
\hline
\end{tabular}

mo, months; DDGS, distillers dried grains with solubles; DM, dry matter; $C P$, crude protein; $E E$, ether extract; $C F$, crude fiber; NDF, neutral detergent fiber; $A D F$, acid detergent fiber, TDN, total digestible nutrient.

1) Rice straw was provided ad libitum throughout the experiment.

${ }^{2)}$ Vitamin premix contained the following amount which was diluted in cellulose (g/kg premix): L-ascorbic acid, 121.2; DL- $\alpha$-tocopherol acetate, 18.8; thiamin hydrochloride, 2.7; riboflavin, 9.1; pyridoxine hydrochloride, 1.8; niacin, 36.4; Ca-D-pantothenate, 12.7; myo-inositol, 181.8; D-biotin, 0.27; folic acid, 0.68; p-aminobenzoic acid, 18.2; menadione, 1.8; retinal acetate, 0.73; cholecalciferol, 0.003 ; cyanocobalamin, 0.003 .

${ }^{3)}$ Mineral premix contained the following ingredients ( $/ \mathrm{kg}$ premix): $\mathrm{Mg} \mathrm{SO}_{4} \cdot 7 \mathrm{H}_{2} \mathrm{O}$, 80.0; $\mathrm{NaH}_{2} \mathrm{PO}_{4} .2 \mathrm{H}_{2} \mathrm{O}, 370.0 ; \mathrm{KCL}$, 130.0; Ferric citrate, 40.0; $\mathrm{ZnSO}_{4} \cdot 7 \mathrm{H}_{2} \mathrm{O}, 20.0$; Ca-lactate, 356.5; $\mathrm{CuCl}, 0.2 ; \mathrm{AlCl}_{3} \cdot 6 \mathrm{H}_{2} \mathrm{O}, 0.15 ; \mathrm{KI}, 0.15 ; \mathrm{Na}_{2} \mathrm{Se}_{2} \mathrm{O}_{3}, 0.01 ; \mathrm{Mn}$ $\mathrm{SO}_{4} \cdot \mathrm{H}_{2} \mathrm{O}, 2.0 ; \mathrm{CoCl}_{2} \cdot 6 \mathrm{H}_{2} \mathrm{O}, 1.0$.

version 9.1 [10]. Genome-wide association analyses were performed according to the method described by Aulchenko et al [11]. At first, slaughter-year-season were fit as a fixed effect and age of month as a covariate, using the SAS general linear model procedure in SAS version 9.1. After that, the fixed or covariate having 0.1 statistical significance level was fit into a mixed model with a genome-relationship matrix ( $G$ matrix) [12], as the pedigree information of the 140 steers was limited. The $\mathrm{G}$ matrix was constructed using an $\mathrm{R}$ subroutine (version 2.15.0), and the residuals of each phenotype were obtained from the equation of mixed model using ASREML (version 3.0). Secondly, the residuals were regressed on each SNP using a simple linear regression model using PLINK version 1.07. For each individual, SNP genotypes for $\mathrm{BB}, \mathrm{BA}$, and $\mathrm{AA}$ were defined as $-1,0$, and 1 , respectively, such that allele substitution effect by replacing $B$ with allele A was estimated for each SNP. To set threshold values of statistical significance, $0.1 \%$ point-wise $\mathrm{p}$-value from the $\mathrm{F}$ distributions was applied for each SNP test.

\section{RESULTS}

The BW change by growth stage and carcass characteristics of Hanwoo steers as influenced by meat yield are presented in Table 2. After 6 months, the highest BW was observed ( $\mathrm{p}<$ $0.05)$ in the greatest MYI group (191 kg) and the lowest ( $\mathrm{p}<$ $0.05)$ in the lowest MYI groups $(174 \mathrm{~kg})$. The great MYI group also showed significantly $(\mathrm{p}<0.05)$ higher BW $(187 \mathrm{~kg})$ than that in the lowest MYI group. After a 16-mo (480 days) growing period, a significant $(\mathrm{p}<0.05)$ weight pattern was observed in the Hanwoo steers as 453, 421, 405, and $385 \mathrm{~kg}$ in the greatest, great, low, and the lowest MYI groups, respectively. The same decreasing pattern from the greatest to the lowest MYI group of Hanwoo steers was observed in the 24-mo growing period (720 days) with a $70.72 \mathrm{~kg}$ difference between the greatest and the lowest MYI group. Based on the average daily weight gain, the BW at day 900 was expected to be the highest in the greatest MYI group $(774 \mathrm{~kg} ; \mathrm{p}<0.05)$. Accordingly, at slaughter, the greatest MYI group had significantly $(\mathrm{p}<0.05)$ the highest carcass weight $(461 \mathrm{~kg})$, followed by great ( $448 \mathrm{~kg}$ ), low (425 $\mathrm{kg}$ ), and then the lowest MYI group (409 kg).

The Pearson correlation analyses of parameters obtained from each treatment are shown in Tables 3, 4, 5, and 6. The BW at the beginning of the experiment in the greatest MYI group was positively correlated to 180 days $(\mathrm{p} \leq 0.01)$ and back-fat thickness ( $\mathrm{p} \leq 0.05)$. After 480 days, the BW was also positively correlated to 720 days' $\mathrm{BW}(\mathrm{p} \leq 0.01)$ and carcass weight ( $\mathrm{p} \leq 0.01)$ with $r=0.574$ and $r=0.655$, respectively. In addition, BW at 720 days was positively correlated to carcass weight $(\mathrm{p} \leq 0.01)$ and eye muscle area $(\mathrm{p} \leq 0.05)$. Highly significant $(\mathrm{p} \leq 0.01)$ positive correlations were also observed between carcass weight and eye muscle area $(r=0.457)$, and between eye muscle area and marbling score $(r=0.473)$. In the great MYI group, positive correlations were observed in the 480 and 720 -days' BW $(\mathrm{p} \leq 0.01)$ and carcass weight and back-fat thickness $(\mathrm{p} \leq 0.01)$. A negative correlation was observed between carcass day and eye muscle area $\left(\mathrm{cm}^{2}\right)$.

The correlation analysis of growth pattern and carcass characteristics of the low MYI group showed that the BW at 180 days was positively correlated to the BW at 480 days ( $\mathrm{p} \leq$ $0.05)$; however, it was negatively correlated to carcass weight $(\mathrm{p} \leq 0.05)$. A highly significant $(\mathrm{p} \leq 0.01)$ positive correlation was observed between the BWs at 480 and 720 days $(r=0.657)$. The carcass weight was also positively correlated to eye muscle 
Table 2. Body weight change by growth stage and carcass characteristics of Hanwoo steers (mean \pm SE) as influenced by meat yield

\begin{tabular}{|c|c|c|c|c|c|c|c|}
\hline \multirow{2}{*}{ Parameters } & \multicolumn{4}{|c|}{ Treatment groups } & \multicolumn{3}{|c|}{ p-value } \\
\hline & Greatest MYI & Great MYI & Low MYI & Lowest MYI & Treat & $\mathrm{L}$ & Q \\
\hline First day weight $(\mathrm{kg})^{1)}$ & $25.09 \pm 0.56$ & $25.40 \pm 0.54$ & $24.83 \pm 0.51$ & $24.60 \pm 0.64$ & ns & ns & ns \\
\hline 180 day weight $(\mathrm{kg})$ & $190.77 \pm 2.55^{\mathrm{a}}$ & $186.51 \pm 3.55^{\mathrm{ab}}$ & $178.26 \pm 3.49^{b c}$ & $173.51 \pm 4.04^{c}$ & ** & ** & ns \\
\hline 480 day weight $(\mathrm{kg})$ & $452.74 \pm 3.78^{\mathrm{a}}$ & $420.57 \pm 3.07^{b}$ & $404.66 \pm 5.82^{c}$ & $384.63 \pm 4.31^{d}$ & ** & ** & ns \\
\hline 720 day weight $(\mathrm{kg})$ & $643.97 \pm 6.78^{\mathrm{a}}$ & $617.74 \pm 4.21^{b}$ & $589.86 \pm 5.18^{c}$ & $573.26 \pm 6.43^{d}$ & ** & ** & ns \\
\hline Average daily gain $(\mathrm{kg} / \mathrm{d})$ & $0.86 \pm 0.01^{\mathrm{a}}$ & $0.82 \pm 0.01^{b}$ & $0.78 \pm 0.01^{c}$ & $0.76 \pm 0.01^{d}$ & ** & ** & ns \\
\hline Expected live weight at $900 \mathrm{~d}(\mathrm{~kg})$ & $773.61 \pm 8.44^{\mathrm{a}}$ & $740.43 \pm 5.35^{b}$ & $706.29 \pm 6.45^{c}$ & $685.82 \pm 7.92^{d}$ & ** & ** & ns \\
\hline Carcass day & $908.45 \pm 3.22$ & $923.60 \pm 3.92$ & $918.72 \pm 6.45$ & $921.42 \pm 7.92$ & - & - & - \\
\hline Carcass weight $(\mathrm{kg})$ & $461.46 \pm 4.98^{\mathrm{a}}$ & $447.83 \pm 4.12^{\mathrm{a}}$ & $425.07 \pm 6.17^{b}$ & $409.23 \pm 5.83^{c}$ & ** & ** & ns \\
\hline Eye muscle area $\left(\mathrm{cm}^{2}\right)$ & $93.12 \pm 1.36^{\mathrm{a}}$ & $90.94 \pm 1.36^{b}$ & $88.97 \pm 2.09^{c}$ & $88.81 \pm 1.42^{d}$ & ns & * & ns \\
\hline Back-fat thickness $\left(\mathrm{cm}^{2}\right)$ & $12.03 \pm 0.75$ & $12.14 \pm 0.71$ & $12.76 \pm 0.86$ & $11.90 \pm 0.72$ & ns & ns & ns \\
\hline Marbling score & $5.76 \pm 0.30$ & $5.94 \pm 0.21$ & $6.24 \pm 0.25$ & $5.48 \pm 0.26$ & ns & ns & ns \\
\hline
\end{tabular}

SE, standard error; MYI, meat yield index; Treat, treatment effect; L, linear effect; $Q$, quadratic effect.

1) First day or birth weight $(\mathrm{kg})$ was received from the farm records and considered as initial body weight for the analysis.

a-d Means in the same row with different superscript letters differ significantly $(p<0.05)$.

Level of significance indicated by ${ }^{*} p<0.05,{ }^{* *} p<0.01$, ns, not significant.

Table 3. Correlation analysis of growth pattern and carcass characteristics of the greatest meat yield group

\begin{tabular}{|c|c|c|c|c|c|c|c|c|c|}
\hline Parameters & First day & 180 day & 480 day & 720 day & $\begin{array}{l}\text { Carcass } \\
\text { weight }\end{array}$ & $\begin{array}{c}\text { Carcass } \\
\text { day }\end{array}$ & $\begin{array}{c}\text { Eye muscle } \\
\text { area }\end{array}$ & $\begin{array}{l}\text { Back fat } \\
\text { thickness }\end{array}$ & $\begin{array}{c}\text { Marbling } \\
\text { score }\end{array}$ \\
\hline First day & 1.000 & $0.592^{* *}$ & -0.233 & 0.096 & -0.104 & 0.302 & -0.269 & $0.416^{*}$ & -0.297 \\
\hline 180 day & - & 1.000 & -0.272 & 0.002 & -0.122 & 0.309 & -0.261 & 0.224 & -0.144 \\
\hline 480 day & - & - & 1.000 & $0.574^{* *}$ & $0.655^{* *}$ & -0.185 & 0.279 & 0.042 & 0.262 \\
\hline 720 day & - & - & - & 1.000 & $0.652^{* *}$ & -0.340 & $0.410^{*}$ & 0.308 & 0.161 \\
\hline Carcass weight & - & - & - & - & 1.000 & 0.026 & $0.457^{* *}$ & 0.095 & 0.220 \\
\hline Carcass day & - & - & - & - & - & 1.000 & 0.015 & -0.047 & -0.270 \\
\hline Eye muscle area & - & - & - & - & - & - & 1.000 & -0.108 & $0.473^{* *}$ \\
\hline Back-fat thickness & - & - & - & - & - & - & - & 1.000 & -0.254 \\
\hline Marbling score & - & - & - & - & - & - & - & - & 1.000 \\
\hline
\end{tabular}

** Values are significantly different $(p \leq 0.01)$.

* Values are significantly different $(p \leq 0.05)$.

Table 4. Correlation analysis of growth pattern and carcass characteristics of great meat yield group

\begin{tabular}{lccccccccc}
\hline Parameters & First day & 180 day & 480 day & 720 day & $\begin{array}{c}\text { Carcass } \\
\text { weight }\end{array}$ & $\begin{array}{c}\text { Carcass } \\
\text { day }\end{array}$ & $\begin{array}{c}\text { Eye muscle } \\
\text { area }\end{array}$ & $\begin{array}{c}\text { Back fat } \\
\text { thickness }\end{array}$ & $\begin{array}{c}\text { Marbling } \\
\text { score }\end{array}$ \\
\hline First day & 1.000 & 0.090 & 0.008 & -0.071 & -0.296 & -0.121 & 0.055 & -0.167 & -0.178 \\
180 day & - & 1.000 & -0.066 & -0.280 & -0.273 & 0.004 & -0.219 & 0.097 & -0.006 \\
480 day & - & - & 1.000 & $0.748^{* *}$ & 0.176 & -0.145 & -0.190 & -0.030 & 0.166 \\
720 day & - & - & - & 1.000 & 0.242 & -0.103 & -0.034 & 0.113 & 0.245 \\
Carcass weight & - & - & - & - & 1.000 & 0.120 & -0.087 & $0.481^{* *}$ & 0.104 \\
Carcass day & - & - & - & - & - & 1.000 & $-0.460^{* *}$ & 0.068 & -0.234 \\
Eye muscle area & - & - & - & - & - & - & 1.000 & -0.119 & 0.231 \\
Back-fat thickness & - & - & - & - & - & - & - & -1.000 & 0.291 \\
Marbling score & - & - & - & - & - & - & - & - & 1.000 \\
\hline
\end{tabular}

** Values are significantly different $(p \leq 0.01)$.

* Values are significantly different $(p \leq 0.05)$.

area $\left(\mathrm{cm}^{2}\right)(\mathrm{p} \leq 0.01)$, back-fat thickness $(\mathrm{p} \leq 0.05)$ and marbling score $(\mathrm{p} \leq 0.05)$. Eye muscle area $\left(\mathrm{cm}^{2}\right)$ was also positively correlated to marbling score $(\mathrm{p} \leq 0.01)$ with $r=0.501$. At the beginning of the experiment, the BW of the lowest MYI group was positively correlated $(r=0.419)$ to the marbling score $(\mathrm{p} \leq 0.05)$. It was also observed that the BWs at 480 and 
Table 5. Correlation analysis of growth pattern and carcass characteristics of low meat yield group

\begin{tabular}{lccccccccc}
\hline Parameters & First day & 180 day & 480 day & 720 day & $\begin{array}{c}\text { Carcass } \\
\text { weight }\end{array}$ & $\begin{array}{c}\text { Carcass } \\
\text { day }\end{array}$ & $\begin{array}{c}\text { Eye muscle } \\
\text { area }\end{array}$ & $\begin{array}{c}\text { Back fat } \\
\text { thickness }\end{array}$ & $\begin{array}{c}\text { Marbling } \\
\text { score }\end{array}$ \\
\hline First day & 1.000 & 0.229 & 0.221 & 0.100 & -0.066 & 0.083 & -0.120 & -0.101 & 0.213 \\
180 day & - & 1.000 & $0.368^{*}$ & 0.315 & $-0.372^{*}$ & 0.112 & -0.342 & 0.070 & 0.135 \\
480 day & - & - & 1.000 & $0.657^{* *}$ & -0.307 & 0.168 & -0.258 & -0.197 & -0.103 \\
720 day & - & - & - & 1.000 & -0.287 & -0.012 & -0.236 & -0.210 & -0.209 \\
Carcass weight & - & - & - & - & 1.000 & -0.031 & $0.623^{* *}$ & $0.382^{*}$ & $0.389^{*}$ \\
Carcass day & - & - & - & - & - & 1.000 & -0.246 & 0.039 & 0.116 \\
Eye muscle area & - & - & - & - & - & - & 1.000 & 0.005 & $0.501^{* *}$ \\
Back-fat thickness & - & - & - & - & - & - & - & -1.000 & 0.027 \\
Marbling score & - & - & - & - & - & - & - & - & 1.000 \\
\hline
\end{tabular}

** Values are significantly different $(p \leq 0.01)$.

* Values are significantly different $(p \leq 0.05)$.

Table 6. Correlation analysis of growth pattern and carcass characteristics of the lowest meat yield group

\begin{tabular}{lccccccccc}
\hline Parameters & First day & $\mathbf{1 8 0}$ day & $\mathbf{4 8 0}$ day & $\mathbf{7 2 0}$ day & $\begin{array}{c}\text { Carcass } \\
\text { weight }\end{array}$ & $\begin{array}{c}\text { Carcass } \\
\text { day }\end{array}$ & $\begin{array}{c}\text { Eye muscle } \\
\text { area }\end{array}$ & $\begin{array}{c}\text { Back fat } \\
\text { thickness }\end{array}$ & $\begin{array}{c}\text { Marbling } \\
\text { score }\end{array}$ \\
\hline First day & 1.000 & 0.156 & 0.232 & 0.186 & -0.126 & -0.252 & -0.110 & 0.049 & $0.419^{*}$ \\
180 day & - & 1.000 & 0.058 & 0.056 & -0.148 & -0.009 & -0.197 & 0.175 & -0.293 \\
480 day & - & - & 1.000 & $0.713^{* *}$ & 0.177 & 0.348 & -0.109 & -0.175 & 0.030 \\
720 day & - & - & - & 1.000 & $0.515^{* *}$ & 0.244 & 0.116 & 0.120 & 0.104 \\
Carcass weight & - & - & - & - & 1.000 & 0.247 & $0.560^{* *}$ & 0.330 & 0.105 \\
Carcass day & - & - & - & - & - & 1.000 & 0.156 & -0.258 & -0.178 \\
Eye muscle area & - & - & - & - & - & - & 1.000 & 0.303 & 0.264 \\
Back-fat thickness & - & - & - & - & - & - & - & 1.000 & 0.175 \\
Marbling score & - & - & - & - & - & - & - & - & 1.000 \\
\hline
\end{tabular}

** Values are significantly different $(p \leq 0.01)$.

* Values are significantly different $(p \leq 0.05)$.

720 days were positively correlated $(\mathrm{p} \leq 0.01)$ to the BW at 720 days $(r=0.713)$ and the carcass weight $(r=0.515)$, respectively. The carcass weight was also positively correlated to eye muscle area.

For carcass traits, twenty-three (23) SNPs were detected (Tables 7,8 ) that were located on Bos taurus autosomes (BTAs)

Table 7. Identities, positions, and effect of the SNPs on carcass weight and eye muscle area of Hanwoo steers

\begin{tabular}{|c|c|c|c|c|c|c|}
\hline SNP marker ${ }^{1)}$ & SNP $^{2)}$ & BTA & Position $^{3)}$ & Additive $^{4)}$ & SEM & $p$-value \\
\hline \multicolumn{7}{|l|}{ Carcass weight } \\
\hline BTB-00986847 & $\mathrm{A} / \mathrm{C}$ & 7 & $1,126,787$ & -6.39 & 2.50 & 0.106 \\
\hline NGS-21607 & $C / T$ & 11 & $100,481,883$ & -9.15 & 3.12 & 0.035 \\
\hline NGS-114518 & $A / G$ & 28 & $40,462,756$ & -4.16 & 1.92 & 0.306 \\
\hline BTB-00995659 & $A / G$ & 28 & $45,898,513$ & -9.19 & 3.95 & 0.204 \\
\hline NGS-28660 & $\mathrm{C} / \mathrm{T}$ & 7 & $4,130,299$ & -1.41 & 0.45 & 0.019 \\
\hline BTB-01280026 & $C / T$ & 14 & $25,170,557$ & 1.58 & 0.68 & 0.208 \\
\hline BTA-00652140 & $C / T$ & 16 & $53,663,332$ & -1.82 & 0.59 & 0.022 \\
\hline BTB-01107683 & $\mathrm{C} / \mathrm{T}$ & 21 & $29,363,186$ & -1.41 & 0.52 & 0.066 \\
\hline NGS-114513 & $\mathrm{A} / \mathrm{G}$ & 28 & $40,462,756$ & -1.32 & 0.46 & 0.039 \\
\hline
\end{tabular}

SNP, single nucleotide polymorphism; BTA, Bos taurus autosome; SEM, standard error of the mean.

${ }^{1,3)}$ SNP marker annotations and their positions.

${ }^{2)}$ Alternative nucleotides, $\mathrm{A} / \mathrm{B}$ alleles such that the estimated additive effect is for allele, $\mathrm{A}$ that is replaced with allele, $\mathrm{B}$.

4) Estimate of additive effect of the SNP.

* Significant SNP marker is indicated by $p<0.01$. 
Table 8. Identities, positions, and effect of the SNPs on back fat thickness and marbling score of Hanwoo steers

\begin{tabular}{|c|c|c|c|c|c|c|}
\hline SNP marker ${ }^{1)}$ & $\mathrm{SNP}^{2)}$ & BTA & Position ${ }^{3)}$ & Additive $^{4)}$ & SEM & p-value \\
\hline \multicolumn{7}{|l|}{ Back-fat thickness } \\
\hline NGS-26771 & $A / G$ & 1 & $69,528,623$ & 1.07 & 0.41 & 0.088 \\
\hline BTA-157501 & $\mathrm{C} / \mathrm{T}$ & 3 & $76,469,248$ & -0.45 & 0.19 & 0.173 \\
\hline NGS-41558 & $\mathrm{A} / \mathrm{C}$ & 3 & $123,148,964$ & -0.77 & 0.29 & 0.083 \\
\hline BTA-160954 & $\mathrm{A} / \mathrm{G}$ & 5 & $18,775,860$ & -0.55 & 0.23 & 0.017 \\
\hline ВTВ-01312166 & $\mathrm{C} / \mathrm{T}$ & 6 & $65,708,017$ & -1.17 & 0.49 & 0.017 \\
\hline BTB-00986847 & $\mathrm{A} / \mathrm{C}$ & 7 & $1,126,787$ & -0.78 & 0.35 & 0.027 \\
\hline \multicolumn{7}{|l|}{ Marbling score } \\
\hline BTA-90292 & $\mathrm{C} / \mathrm{T}$ & 2 & $90,639,723$ & 0.46 & 0.17 & 0.163 \\
\hline BTA-104512 & $\mathrm{A} / \mathrm{G}$ & 4 & $112,700,199$ & -0.3 & 0.09 & 0.013 \\
\hline BTB-160954 & $\mathrm{A} / \mathrm{G}$ & 5 & $18,775,860$ & -0.26 & 0.09 & 0.061 \\
\hline NGS-8401 & $\mathrm{G} / \mathrm{T}$ & 5 & $76,428,730$ & -0.17 & 0.08 & 0.384 \\
\hline NGS-43407 & $\mathrm{A} / \mathrm{G}$ & 5 & $110,911,478$ & 0.22 & 0.08 & 0.045 \\
\hline ВТВ-00986847 & $\mathrm{A} / \mathrm{C}$ & 7 & $1,126,787$ & 0.29 & 0.12 & 0.039 \\
\hline
\end{tabular}

SNP, single nucleotide polymorphism; BTA, Bos taurus autosome; SEM, standard error of the means.

1,3) SNP marker annotations and their positions.

${ }^{2)}$ Alternative nucleotides, $\mathrm{A} / \mathrm{B}$ alleles such that the estimated additive effect is for allele, $\mathrm{A}$ that is replaced with allele, $\mathrm{B}$.

4) Estimate of additive effect of the SNP.

$1,2,3,4,5,6,7,11,14,16,21$, and 28 . Among the 23 SNPs, only BTB- 1280026 SNP was significantly $(\mathrm{p}<0.01)$ related to carcass weight with an additive effect of $12.4 \mathrm{~kg}$ for increasing $\mathrm{C}$ alleles over $\mathrm{T}$ alleles. However, for eye muscle area, backfat thickness, and marbling score, there was limited statistical support for the association of the SNPs (Tables 7, 8).

\section{DISCUSSION}

In the literature, the relationship between growth, feed efficiency, and carcass composition is reported as mainly dependent on feed management in terms of the composition of the diet or the amount of food (restricted versus ad libitum) [13-16]. Breed type, age, and weight at slaughter also influence the relationship between the traits $[14,15,17]$. However, in the present study, rice straw was given ad libitum, whereas concentrate feed was fed at $5.71 \mathrm{~kg}$ during the growing period ( 6 to $13 \mathrm{mo}$ ) and $9.4 \mathrm{~kg}$ during the middle fattening period (13 to $28 \mathrm{mo}$ ) to minimize the effect of the feed on BW gain and carcass weight.

In this experiment, the live and carcass weight, eye muscle area, and back-fat thickness was observed to be the highest in the greatest MYI group. This greatest MYI group had a significant $(\mathrm{p} \leq 0.01)$ positive correlation with live and carcass weight indicating a strong genetic correlation between live growth with carcass weight. There was also a significant correlation found in the greatest MYI group between carcass weight and eye muscle area as well as between eye muscle area and marbling score indicating the meat quality trait was also influenced by the greatest genotyped animals. This finding is consistent with that of Johnson et al [18], who reported a high and positive ( 0.64 to 0.97$)$ genetic and phenotypic cor- relation between steer live weight and hot carcass weight. The genetic correlation between live animals and carcasses were also consistent with the reports for other beef cattle breeds [19-21]. A significant reduction in carcass day was also recorded in the greatest MYI group, which is expected by farmers. Lowering the carcass day has a positive impact on the reduction of total feed cost as steers slaughtered at the earliest age consume less feed overall [22]. In Table 2, eye muscle area $\left(\mathrm{cm}^{2}\right)$ was decreasing linearly from the greatest to lowest group however in correlation analysis of the Great MYI group showed a significant negative correlation between carcass day and eye muscle area which was unexpected. This is may be due to their transfer to slaughterhouse at last as a result they received much more psychological stress which affects feed consumption and subsequently carcass quality and quantity [23].

Among the identified 23 SNPs, only the BTB-1280026 SNP was significantly associated with carcass weight. The number of steers for meat quality analysis in this study was very limited $(n=140)$, which may not enable detection of many SNPs for carcass quality traits with strong statistical evidence. As the sample size is one of the major factors for SNP detection in genome-wide association analysis [24], more samples are needed to detect QTL with strong statistical support, and the detected QTL (SNP) subsequently need to be validated by the addition of more samples. However, this study was in partial agreement with that of $\mathrm{Lu}$ et al [25], who found eight SNPs that were associated with hot carcass weight in 747 genotyped animals and 7 of which were located on BTA6. However, 520 SNPs were found significantly associated with mostly individual traits (473 SNPs), and multiple traits (47 SNPs) based on less stringent significance level $(\mathrm{p}<0.001)$ and 22 of SNPs out of 48 , located on BTA6, were associated 
with hot carcass weight. Likewise, Edea et al [7] identified 17 and 16 QTLs that were significantly $(\mathrm{p}<0.01)$ associated with carcass weight under the additive and dominant models, respectively. They also mentioned that BTA 2, 6, 14, 22, and 24 loci were previously identified in several beef cattle breeds as QTL for carcass weight. In this study, BTB-1280026, the identified significant carcass weight-related SNP, was located on BTA 14, which was strongly supported by the results of Rempel et al [26], who identified carcass weight-related QTL (21.1 to $21.1 \mathrm{Mb}$ ) on BTA 14 in crossbred beef cattle. In addition, the QTLs on BTA 14 are also highly associated with body size in taurine and zebu cattle [27].

\section{CONCLUSION}

The genetic MYI for calf selection is an important factor in determining beef quantity. Our results show that the use of the genetic MYI could reduce the slaughter age, while simultaneously increasing carcass weight as well as back-fat thickness and marbling score. High-density bovine SNP array analysis showed that one SNP, BTB-01280026, was found for carcass weight with strong statistical support, and the steers with the allele for increasing carcass weight had slaughter weight that was greater by about $12 \mathrm{~kg}$ than the animals with an alternate decreasing allele.

\section{CONFLICT OF INTEREST}

We certify that there is no conflict of interest with any financial organization regarding the material discussed in the manuscript.

\section{ACKNOWLEDGMENTS}

This work was supported by Korea Institute of Planning and Evaluation for Technology in Food, Agriculture and Forestry (IPET) through Advanced Production Technology Development Program, funded by Ministry of Agriculture, Food and Rural Affairs (MAFRA) (Project No. 317016-03-3-WT011).

\section{REFERENCES}

1. Lee SH, Park BH, Sharma A. Hanwoo cattle: origin, domestication, breeding strategies and genomic selection. J Anim Sci Technol 2014;56:2. https://doi.org/10.1186/2055-0391-56-2

2. Park B, Choi T, Kim S, Oh SH. National genetic evaluation (system) of Hanwoo (Korean native cattle). Asian-Australas J Anim Sci 2013;26:151-6. https://doi.org/10.5713/ajas.2012. 12439

3. Ponzoni RW, Newman S. Developing breeding objectives for Australian beef cattle production. Anim Prod 1989;49:35-47. https://doi.org/10.1017/S0003356100004232
4. Fernández-Perea M, Jiménez RA. Economic weights for a selection index in Avileña purebred beef cattle. Livest Prod Sci 2004;89:223-33. https://doi.org/10.1016/j.livprodsci.2004. 01.004

5. Koots KR, Gibson JP. Economic values for beef production traits from a herd level bioeconomic model. Can J Anim Sci 1998;78:29-45. https://doi.org/10.4141/A97-038

6. Rios-Utrera A, Van-Vleck LD. Heritability estimates for carcass traits of cattle: a review. Genet Mol Res 2004;3:380-94.

7. Edea Z, Jeoung YH, Shin SS, et al. Genome-wide association study of carcass weight in commercial Hanwoo cattle. AsianAustralas J Anim Sci 2018;31:327-34. https://doi.org/10.5713/ ajas.17.0276

8. National Livestock Cooperatives Federation (NLCF). Korean carcass grading standard. Seoul, Korea: National Livestock Cooperatives Federation; 2004.

9. Purcell S, Neale B, Todd-Brown K, et al. PLINK: a tool set for whole-genome association and population-based linkage analyses. Am J Hum Genet 2007;81:559-75. https://doi.org/ $10.1086 / 519795$

10.SAS. SAS/STAT. Statistical analysis systems for windows. Release 9.1. Cary, NC, USA: SAS Institute Inc.; 2004.

11.Aulchenko YS, De Koning DJ, Haley C. Genomewide rapid association using mixed model and regression: a fast and simple method for genomewide pedigree-based quantitative trait loci association analysis. Genetics 2007;177:577-85. https:// doi.org/10.1534/genetics.107.075614

12. Van-Raden PM. Efficient methods to compute genomic predictions. J Dairy Sci 2008;91:4414-23. https://doi.org/10.3168/ jds.2007-0980

13. Bailey CM, Liboriussen T, Andersen H, Andersen BB. Producing beef from intact male progeny of Holstein sires: feed efficiency and compositional characters. J Anim Sci 1985;61: 27-35. https://doi.org/10.2527/jas1985.61127x

14. Bond J, Warwick E, Oltjen R, et al. Effects of feeding level on growth, composition of gain, carcass quality and mature body size in steers at ages up to six years. Growth 1982;46:388-403.

15.Loerch S, Fluharty F. Effects of programming intake on performance and carcass characteristics of feedlot cattle. J Anim Sci 1998;76:371-7. https://doi.org/10.2527/1998.762371x

16. Moloney AP, Allen P, Ross DB, Olson G, Convey EM. Growth, feed efficiency and carcass composition of finishing Friesian steers fed the beta-adrenergic agonist L-644,969. J Anim Sci 1990;68:1269-77. https://doi.org/10.2527/1990.6851269x

17. Mandell I, Gullett E, Wilton J, Allen O, Kemp R. Effects of breed and dietary energy content within breed on growth performance, carcass and chemical composition and beef quality in Hereford and Simmental steers. Can J Anim Sci 1998;78:533-41. https://doi.org/10.4141/A97-101

18. Johnson DL, Baker RL, Morris CA, Carter AH, Hunter JC. Reciprocal crossbreeding of Angus and Hereford cattle 2. Steer growth and carcass traits. New Zeal J Agric Res 1986; 
29:433-41. https://doi.org/10.1080/00288233.1986.10423495

19. Fouilloux MN, Renand G, Gaillard J, Ménissier F. Genetic parameters of beef traits of Limousin and Charolais progenytested AI sires. Genet Sel Evol 1999;31:465. https://doi.org/10. 1186/1297-9686-31-5-465

20.Splan R, Cundiff LV, Dikeman M, Van Vleck LD. Estimates of parameters between direct and maternal genetic effects for weaning weight and direct genetic effects for carcass traits in crossbred cattle. J Anim Sci 2002;80:3107-11. https:/doi. org/10.2527/2002.80123107x

21.Eriksson S, Näsholm A, Johansson K, Philipsson J. Genetic analyses of field-recorded growth and carcass traits for Swedish beef cattle. Livest Prod Sci 2003;84:53-62. https://doi.org/10. 1016/S0301-6226(03)00049-6

22. Goddard ME, Hayes BJ. Mapping genes for complex traits in domestic animals and their use in breeding programmes. Nat Rev Genet 2009;10:381-91. https://doi.org/10.1038/nrg2575

23. Costa LN. Short-term stress: the case of transport and slaughter. Ital J Anim Sci 2009;8:241-52. https://doi.org/10.4081/ijas. 2009.s1.241

24. Prado IN, Eiras CE, Fugita CA, et al. Animal performance and carcass characteristics of bulls (1/2 Purunã vs $1 / 2$ Canchim) slaughtered at 16 and 22 months old, and three different weights. Asian-Australas J Anim Sci 2015;28:612-9. https:// doi.org/10.5713/ajas.14.0793

25.Lu D, Sargolzaei M, Kelly M, et al. Genome-wide association analyses for carcass quality in crossbred beef cattle. BMC Genet 2013;14:80. https://doi.org/10.1186/1471-2156-14-80

26. Rempel LA, Casas E, Shackelford SD, Wheeler TL. Relationship of polymorphisms within metabolic genes and carcass traits in crossbred beef cattle. J Anim Sci 2012;90:1311-6. https://doi.org/10.2527/jas.2011-4302

27. Utsunomiya YT, do Carmo AS, Carvalheiro R, et al. Genomewide association study for birth weight in Nellore cattle points to previously described orthologous genes affecting human and bovine height. BMC Genet 2013;14:52. https://doi.org/ 10.1186/1471-2156-14-52 